Hans Petter Graver

Professor dr. juris

Universitetet i Oslo

\title{
Kafkas 5 teser om Lovspråk \\ Om hvordan lovens lovhet påvirker lovspråket
}

I Kafkas fortelling «Foran loven» kommer en mann til loven. Foran lovens åpne port står en portvokter. Mannen og vokteren er ikke jevnbyrdige. Mannen er «en mann fra landet» og kommer ikke fra der hvor loven lages og voktes. Vokteren er en del av loven. Han er pelskledd, et tegn på sosial status og står der med det «lange glisne sorte tartariske skjegget» som en av embetsverkets fjerne mandariner.

Lovspråket utøver makt. Det forbyr, påbyr, tillater og fritar. Uansett hvor vennlig og forlokkende budskapet pakkes inn er det likefulltet maktbudskap. Loven innbyr ikke til diskusjon eller refleksjon, og kommunikasjonen med loven er ikke en kommunikasjon mellom likeverdige. Med loven føres ingen samtale. Dette er

\section{Kafkas forste tese om lovspråket:}

Lovkommunikasjonen preges av ujevnbyrdighet mellom avsender og mottaker.

«Det er mulig», sier vokteren, «men ikke nå». Mannen fester seg ved det første, og legger ikke merke til annet enn loven og portvokteren, ikke til blomster og dyr, ikke til skiftende årstider, at årene går. Han legger heller ikke merke til at ingen andre kommer og vil inn til loven. Han er alene med loven og vokteren, men enser det ikke.

Det viktige er ikke hva loven betyr, men hva den betyr for deg. I sin utilgjengelighet signaliserer den et håp, og dette håpet klamrer mannen seg til helt til sin død. Kanskje finnes det andre veier inn til loven? Kanskje loven faktisk ikke er for ham, kanskje har han rett og slett ikke rett. Alle håper på å ha rett og oppfatter loven ut fra dette. Det er vanskelig å se bort fra det som er viktig, men som likevel ikke har betydning i forhold til lovens strenge saklighet. Kanskje er dét en grunn til at de ikke forstår den og at mannen kaster bort livet sitt på en rett han ikke har. Håpet om en dag om å komme inn gjør at han ikke fatter budskapet som ligger i at dørvokteren stadig sier «men ikke nå». Dette er

\section{Kafkas andre tese om lovspråket:}

Troen på å ha rett gjør det vanskelig å forstå lovens egentlige budskap.

Retten er forlokkende. Mannen har utrustet seg godt for reisen og anvender alt, uansett hvor kostbart det er for å bestikke dørvokteren. Advokatsalærer og sportler må betales uansett om man får rett eller ikke. Det koster å strebe etter retten, retten har sin pris. Det er det som gjør den verdt å strebe etter? 
Rettens pris er ikke bare de direkte utleggene. Mannens streben etter retten påvirker hele livet hans. Det påvirker hans forhold til familie og venner, hans sosiale relasjoner endres av hans forsøk på å slippe inn til loven. Portvokteren tar imot mannens bestikkelser, bare for at mannen ikke skal tro at han har latt noe være uforsøkt. Slik øker verdien av å komme inn for mannen, uten at det påvirker hans mulighet til å komme inn til loven. Hvis det er enkelt å komme inn i loven, blir loven verdiløs. Dette er

\section{Kafkas tredje tese om lovspråket: \\ Lovens utilgjengelighet øker dens verdi.}

Dørvokteren er ikke alene. Vokteren inngår i et nettverk av voktere. Vokteren samler opplysninger om mannen på vegne av andre som lever av å katalogisere, behandle og arkivere dem. Vokteren forsyner et helt apparat av funksjonærer med arbeid. Det er også de som lever av vokteren. På hans pelskrage kryper lopper som mannen appellerer til for hjelp. Var det ingen vokter, var det ingen for loppene å leve av. Vokterens funksjon er mye mer enn å holde mannen ute. Vokteren holder liv i mange.

Det er få tekster det ligger så mye arbeid og oppmerksomhet bak som lovtekster. I konsis form skal kompliserte og ofte kontroversielle budskap uttrykkes. Tekstene foreslås av sekretærer, diskuteres av utvalg, kommenteres av høringsinstanser og knas i departementer. Så forhandles de politisk i regjeringen og Stortinget. Alt dette arbeidet øker ikke alltid deres språklige tilgjengelighet.

Teksten skal tilgodese forskjellige interesser, den skal ta forbehold for bestemte situasjoner eller konsekvenser og skal uttrykke eller dekke over kompromisser. Lovens utilgjengelighet er således resultat av at mange krefter påvirker. Dette er

\section{Kafkas fjerde tese om lovspråket:}

Lovens språk tjener mange interesser.

Mannen glemmer etterhånden de andre portvokterne som står fra sal til sal innenfor. Han forbanner den første vokteren som forekommer ham å være den eneste hindringen. Men de andre vokterne er større og mektigere enn den første. «Bare synet av den tredje tåler ikke engang jeg» sier portvokteren. Hindringene inn til loven ligger således ikke bare i overflaten, i språket. I lovens indre er hindringene større og flere. Hvor langt inn må mannen for å få adgang til loven? Hvor mange voktere må han passere for å få rett?

\section{Kafkas femte tese om lovspråket:}

Lovens språk er ikke den eneste skranke for adgangen til loven.

Kafka gir oss gjennom fortellingen flere observasjoner som belyser vanskene med å trenge inn i loven. Lovspråket preges av ujevnbyrdighet mellom avsender og mottaker, troen på å ha rett gjør det vanskelig å forstå lovens egentlige budskap, lovens utilgjengelighet øker dens verdi, lovens språk tjener mange interesser og lovens språk er ikke den eneste skranke for adgangen til loven - disse er gyldige teser om lovspråket også i dag. De uttrykker noe sentralt 
om lovenes «lovhet», det som gjør lovtekster til nettopp lovtekster. Loven har en lovhet som tilsynelatende er uavhengig av tid, sted og rom, i alle fall innenfor vår vestlige rettstradisjon. Lovtekstens utforming må ta hensyn til lovens lovhet, til sjangeren om man vil.

Loven er maktens språk. Dens språk er plikt, forbud og autoritet. Dette gjelder også i en tid hvor dialog, likeverd og kompromiss er mer moderne. Moderne mennesker er rett og slett ikke vant til rettens modaliteter, noe som gjør loven vanskeligere å uttrykke på en forståelig måte. «Alle» har en fornemmelse for hva som er rett. Vi blander rett og moral og leser loven på bakgrunn av hva vi tror må være rett. Dette gjør at folk ikke alltid oppfatter nyansene, forbeholdene og avvikene i loven fra det de oppfatter som rett og rimelig. Dette bekreftes av undersøkelser om folks kunnskaper om og holdninger til loven. Å skaffe seg innsikt i sin rettssituasjon blir i vårt komplekse samfunn mer og mer ressurskrevende.

At lovens ordlyd ofte er resultat av kompromisser hvor flere skal ha sitt er en kjent sak. Noen ganger er ordlyden derfor bevisst uklar for å gi rom for flere tolkninger eller for å dekke over en uenighet. Og endelig, det er fortsatt sant at språket bare er en av mange barrierer til innsikt i hva loven innebærer. Reglenes fragmentariske karakter og mengden av regler gjør at man ofte får et misvisende bilde av bare å lese en lovtekst. Loven er abstrakt, og vanskene består ofte ikke å avgjøre hva den generelt sett betyr, men hva den betyr og innebærer i det enkelte tilfellet er ofte vanskelig å avgjøre. Og det klassiske skillet mellom lovens bokstav og dens ånd og betydningen av begge for å avgjøre lovens innhold er like aktuelt i dag som $\mathrm{i}$ antikken. For å få kunnskap om hva som ligger i lovens ånd og avveiningen mot ordlyden, må man ofte gå til andre kilder enn lovteksten.

Kafkas teser forteller oss noe om vanskelighetene med å gjøre loven tilgjengelig slik at folk kan få adgang til den. Vi må gjøre den første porten, språket, så åpen som mulig. Samtidig må vi ikke være naive og tro at loven alltid blir forståelig selv med et enkelt språk. Kanskje er et språk mange oppfatter som vanskelig nødvendig for å uttrykke lovens modaliteter, abstraksjonsnivå, forbehold og sosiale og politiske funksjon.

Kvalitet i språket er viktig for at loven skal bli så forståelig som mulig, og for at den skal bli presis og gi god veiledning for profesjonelle rettsanvendere. Men lovspråket og dets stil dreier seg om mer enn bare dette. Ser man på en av de eldste norske lovtekster i dag, Grunnloven av 1814, så ser man at den er vanskelig å forstå ikke fordi språket i den er dårlig, men fordi det er fremmed og annerledes.

Grunnloven har gjennomgående et meget godt og presist språk som tydeligvis er utformet med stor bevissthet. Dens fremmedhet skyldes ikke bare avstanden i tid. Fremmedheten skyldes også at det ikke er en vanlig lovgiver som opptrer ikledd grunnlovens språkdrakt. Gjennom utformingen av språket fremtrer grunnlovgiveren med en tydelig og markert identitet, det er Riksforsamlingen på Eidsvoll som deklamerer etter 500 år under danskestyre at «Kongeriket Norge er et frit, uafhængigt og udeleligt Rige. Dets Regjeringsform er indskrænket og arvelig-monarkisk.» Kongeriket Norge er, og regjeringsformen er innskrenket. Slik skriver en grunnlovsgiver. ${ }^{1}$

\footnotetext{
${ }^{1}$ Etter språkreformen i 2014 står det i bokmålsversjonen «Kongeriket Norge er et fritt, selvstendig, udelelig og uavhendelig rike. Dets regjeringsform er innskrenket og arvelig monarkisk» og i nynorskversjonen «Kongeriket
} 
Lovspråket har således med den identitet og personlighet lovgiveren ønsker å fremstå med. Enevoldskongen fremsto som fyrsten av Guds nåde - i 1687 skrev den dansk-norske kongen Christian V:

VI CHRISTIAN DEN FEMTE af Guds Naade, Konge til Danmark og Norge, de Venders og Gothers, Hertug udi Slesvig, Holsten, Stormarn og Dytmersken, Greve udi Oldenborg og Delmenhorst, giøre hermed for alle vitterligt $[\ldots]$ (Christian Vs norske lov, fortale)

Dagens EU-lovgiver fremstår som eksperten:

I Fællesskabets program for politik og handling i forbindelse med miljøet og bæredygtig udvikling (femte miljøhandlingsprogram) fastslås det, at opnåelse af en bæredygtig udvikling kræver gennemgribende ændringer i de nuværende udviklings-, produktions-, forbrugs- og adfærdsmønstre, og der slås bl.a. til lyd for mindskelse af unødvendigt forbrug af naturressourcer og forebyggelse af forurening. (Europa-

Parlamentets og Rådets direktiv 2012/19/EU af 4. juli 2012 om affald af elektrisk og elektronisk udstyr)

Hvem og hva er det dagens moderne norske lovgiver ønsker å fremstå som?

I begrunnelsen for klarspråkprosjektet i staten står det at «informasjon fra det offentlige skal være forståelig for alle» og språket «klart og brukertilpasset»:

Klarspråk er en tilnærming til kommunikasjon som

- $\quad$ setter leseren først

- fokuserer på handling

- $\quad$ sparer tid og penger

- gjør dokumenter mer etterrettelige og gjennomskinnelige

- fører til en bedre opplevelse for mottakeren. (Om klarspråk udatert)

Leseren skal «settes» først, det skal «fokuseres på handling» og leseren skal få en bedre «opplevelse». Riktignok bruker ikke teksten passiv, men subjektet er en abstraksjon: «Klarspråk». Hvem er nå det? Han eller hun er ikke mye mer personlig enn en av Kafkas voktere. Vi får ikke vite mer om ham eller henne at han/hun er en tilnærming.

Uavhengig av hvem denne «Klarspråk» er, har han eller hun tilsynelatende mål som ligger langt unna lovenes tradisjonelle lovhet. Kan det være at man har fătt bukt med den tradisjonelle lovheten til lovene slik at det som gjenstår nå er å få uttrykt dette klart slik at alle forstå det? Jeg tror ikke det. For de fleste vil det uansett hvor mye Klarspråk bestreber seg aldri bli noen god opplevelse når lovens budskap siger inn og de forstår at de har en tapt sak eller må bøye seg for lovens autoritet. Loven er befaling, den pålegger plikter og stiller opp forbud - og selv der den gir rettigheter setter den grenser.

For dagens mennesker er grensesetting et fremmedord. Hvordan kan vi forvente av dem som ikke vet hva grensesetting er at de skal lett kunne forstå loven? I et demokratisk og mangfoldig samfunn hvor alle skal ha lik rett til å påvirke beslutninger vil loven være preget av kompromisser med de følger dette har for klarhet og gjennomførbarhet. Og loven må alltid leses med forbehold, i økende grad i et komplekst samfunn med en uoversiktlig regulering.

Noreg er eit fritt, sjølvstendig, udeleleg og uavhendeleg rike. Regjeringsforma er avgrensa og arveleg monarkisk». Fortsatt er det grunnlovsgiveren som skriver. 
Klarspråk endrer ikke lovens lovhet. Men klarspråkarbeidet forteller oss hva som er dagens lovgiverideal, hvordan lovgiveren ønsker å fremstå. Ikke som en autoritær fyrste, ikke som en komité av teknokrater, men som en omsorgsperson som tar folk på alvor, er handlingsorientert og tar ansvaret for folks gode opplevelser. Dette er vel og bra, og det er kanskje også det synet på staten som folk vil ha i en tid hvor stadig mer av tilværelsen dreier seg om å konsumere det som kommer fra underholdningsindustrien og velferdssektoren. Og det er viktig å gi folk det de vil ha. Men det er også viktig ikke å kaste dem blår i øynene.

\section{Litteratur}

Kafka, F. (2005). Kafkas beste. Oversatt av Trond Winje. s. 623-624. Oslo: Gyldendal

Christian Vs norske lov, Lov 15. april 1687. Tilgjengeliggjort av Institutt for arkeologi, konservering og historie, UiO på http://www.hf.uio.no/iakh/forskning/prosjekter/tingbok/kilder/chr5web/chr5register.html

Europa-Parlamentets og Rådets direktiv 2012/19/EU af 4. juli 2012 om affald af elektrisk og elektronisk udstyr. Om klarspråk. (udatert). Hentet 07.10.2013, fra http://www.sprakrad.no/Klarsprak/Diverse/Toppmeny5/Omklarspraak/ 